\title{
Seasons and water container types affecting Culex spp. in southern Thailand
}

\author{
Anantanit Chumsri • Fahmida Wazed Tina ID - Mullica Jaroensutasinee - Krisanadej Jaroensutasinee
}

A Chumsri - M Jaroensutasinee (Corresponding author) K Jaroensutasinee

Centre of Excellence for Ecoinformatics, School of Science, Walailak University, Nakhon Si Thammarat 80161, Thailand. email: mullica.jn@gmail.com

\section{FW Tina}

Nakhon Si Thammarat Rajabhat University, Tha Ngio, Nakhon Si Thammarat 80280, Thailand.

Received: October 05, 2019 • Accepted: October 22, 2019 • Published Online: November 15, 2019

\begin{abstract}
Usually, Culex mosquitoes are responsible for spreading several human diseases such as malaria, Japanese encephalitis, yellow fever, filariasis, and Zika. Lymphatic filariasis and Zika cases are increasing in Thailand with more prevalent in southern Thailand. In this study, our aim is to examine how seasons and water container types affect Culex spp. larvae numbers in Lansaka district, Nakhon $\mathrm{Si}$ Thammarat province, southern Thailand. This study was conducted in five sub-districts (Lansaka, Khaokaew, Thadi, Kamlon, and Khunthale) in Lansaka district. In each subdistrict, 120 houses were randomly selected to study the breeding sites of Culex mosquito in dry (March-May, 2018) and wet (October-December, 2018) seasons. Mosquito larvae were collected from indoor, outdoor, natural, artificial, darkcoloured, light-coloured, with lid, and without lid containers. It was observed that in all sub-districts, Culex larvae numbers were higher in dry season compared to wet season. In both seasons, outdoor, without lid, dark-coloured, and artificial containers contained more Culex larvae than inside, with lid, light-coloured, and natural containers, respectively. This study shows that seasons and water container types affect Culex mosquito larvae. Since the larvae numbers are higher in dry season, as well as in outdoor, without lid, dark-coloured, and artificial containers, people should reduce the usage of these containers, especially in the dry season, to prevent Culex borne diseases.
\end{abstract}

Keywords: dry and wet seasons, Lansaka district, mosquito larvae, Nakhon Si Thammarat, positive containers

\section{Introduction}

Nowadays, mosquito-borne diseases are major public health problems in many parts of the world (Dass and Mariappan 2014; Nadeeka et al 2014). There are more than 4,500 mosquito species distributed throughout the world, belonging to 34 genera; however, most of these species belong to genus Aedes, Anopheles, and Culex (Chandra et al 2013). Culex mosquitoes are responsible for spreading various types of infectious diseases, such as Japanese encephalitis, West Nile fever, St. Louis encephalitis, filariasis, and avian malaria (Lalubin et al 2013). Among these diseases, Japanese encephalitis is endemic in more than 20 countries (Kumar 2014), and is spreading out to new territories very quickly (Erlanger et al 2009); around three billion people are at risk of this disease (Shad and Andrew 2016). Filariasis is known as another major health problem worldwide. Lymphatic filariasis is widespread throughout tropical and subtropical areas of the world, with nearly $20 \%$ population worldwide are at risk of filarial infection (Shad and Andrew 2016). Recently, Culex coronator, Cx. tarsalis, and Cx. quinquefasciatus have been reported as potential vectors for the transmission of the Zika virus in Brazil, China, and Mexico (Guo et al 2016; Guedes et al 2017; Elizondo-Quiroga et al 2018).

In order to prevent Culex borne diseases more effectively, it is essential to investigate the effect of different factors and their interactions (e.g., season, breeding sites, the socio-cultural practices of people etc.). Female mosquitoes usually breed in various types of water containers (e.g. water storage containers, animal feeding pans, trash containers, coconut shells, and used tires). Normally, these containers can be divided into four groups (indoor/outdoor, natural/artificial, dark/light, and with/without lids) (Wongkoon et al 2007a, b; Hribar 2006; Chumsri et al 2018). Previous studies reported that female mosquitoes preferred outdoor, artificial, dark, and without lid containers than indoor, natural, light and containers with a lid, respectively (Preechaporn et al 2007; Wongkoon et al 2007a; Idowu et al 2012, Thete and Shinde 2013; Chumsri et al 2018). The wet and dry seasons have been reported to have strong effects on mosquito abundance. Most studies observed higher numbers of Culex spp., Aedes albopictus, and Anopheles maculatus in the wet season than in dry season (Rattanarithikul et al 1996; Ahmed et al 2007; Preechaporn et al 2007; Aziz et al 2012; Chumsri et al 2018). 
On the other hand, the numbers of Anopheles dirus and Aedes aegypti were higher in the dry season than in the wet season (Rattanarithikul et al 1996; Preechaporn et al 2007; Lambdin et al 2009; Chumsri et al 2018).

More than 700 cases associated with Culex borne diseases in Thailand were reported in 2018 (i.e. 657 Japanese encephalitis cases and 111 lymphatic filariasis cases) (Bureau of Epidemiology 2018). Lymphatic filariasis cases are on the rise and more prevalent in southern Thailand (Bureau of Epidemiology 2018). Recent studies have reported that Culex could be one of the vectors of the Zika virus. In the past three years in Thailand, a significant number of Zika cases has been reported (i.e., 1114 Zika cases in 2016 from 43 out of 77 provinces, 577 Zika cases in 2017, from 33 out of 77 provinces, and 612 Zika cases in 2018, from 37 out of 77 provinces). Since Ae. aegypti and Culex spp. both act as vectors of the Zika virus, controlling Ae. aegypti populations only may not reduce Zika virus transmission in Thailand. Effective vector control strategies may need to take initiatives to control both Culex and Ae. aegypti populations For this reason, it is important to identify breeding sites of Culex mosquitoes in southern Thailand. Our aim is to conduct research in five sub-districts in Lansaka district to test the effects of seasons and water containers on Culex larvae numbers in different sub-districts.

\section{Materials and Methods}

Study site

This study was conducted in five sub-districts (Lansaka, Khaokaew, Thadi, Kamlon, and Khunthale) in Lansaka district, Nakhon Si Thammarat province, southern Thailand $\left(8.40700^{\circ} \mathrm{N}\right.$ and $99.76891^{\circ} \mathrm{E}$ ) (Figure 1). The average altitude of our study site is $349 \mathrm{~m}$.

\section{Mosquito larvae collection}

In each sub-district, 120 houses were randomly selected to study breeding sites of Culex mosquitoes in dry (March-May, 2018) and wet (October-December, 2018) seasons. In each house, mosquito larvae were collected from different kinds of water containers (e.g., water-storing containers (water jars, water tanks, water buckets, and etc.), plant pots, feeding pans of animals, lids of water containers, trash containers, coconut shells, and etc.) by using $0.55 \mathrm{~mm}$ mesh-sized fishnets. Afterward, the larvae were preserved in $70 \%$ ethanol. These water containers were divided into four categories (indoor/outdoor (containers found inside or outside houses), natural/artificial (not man-made or man-made containers), dark/light (dark-coloured or light-coloured containers), with/without lid (containers with or without lid covers)) based on Phuanukoonnon et al (2005), Wongkoon et al (2007b), Promprou et al (2007), Bartlett-Healy et al (2012), and Chumsri et al (2018).

The collected mosquito larvae were taken to the laboratory at Walailak University, Nakhon Si Thammarat province for identification. Each mosquito larva was identified up to the genus level based on Rattanarithikul and Panthusiri's keys (Rattanarithikul and Panthusiri 1994). In this study, only Culex mosquito larvae were taken into account; other mosquito larvae species were not used.

\section{Environmental conditions of the study site}

The average temperature, rainfall, and relative humidity of Lansaka district in 2018 are provided in table 1. Data were collected by the Centre of Excellence for Ecoinformatics, Walailak University, Thailand.

\section{Statistical analysis}

Chi-square tests were used to test (1) the differences in Culex larvae numbers between the dry and wet seasons in each sub-district; (2) the differences in Culex larvae numbers among sub-districts in both seasons, (3) the differences in larvae numbers between indoor and outdoor, between with and without lids, between light and dark, and between natural and artificial containers, in each sub-district in both seasons, (4) the differences in the numbers of different kinds of containers in each sub-district in both seasons, and (5) the differences in the numbers of total/positive containers belong to each container group, among the sub-districts in both seasons. Statistically significance level was considered to be at $P<0.05$.

\section{Results}

Seasons, sub-districts, water container types, and Culex larvae

In all sub-districts, Culex larvae numbers were higher in the dry season than in the wet season (Table 2). In the wet season, Culex larvae were found more in Khunthale than in other sub-districts. In the dry season, the larvae were found more in Khaokaew than in other sub-districts (Table 2).

Culex larvae were higher in numbers in outdoor, without a lid, dark, and artificial containers compared to indoor, with a lid, light, and natural containers, respectively, in both the dry and wet seasons (Table 3).

\section{Differences in the usage of water containers}

In all sub-districts, the numbers of total containers were higher in the wet season than in the dry season (Table 4). Whereas the positive containers were more in numbers in the dry season than in the wet season in Khaokaew, Lansaka, Thadi, and Kamlon sub-districts, but the numbers were not different between seasons in Khunthale (Table 4). 
In all sub-districts in both dry and wet seasons, people used higher number of water storing containers compared to other kind of containers (Table 5). In the case of positive containers in dry season, water-storing containers were more in numbers compared to other kind of containers in all subdistricts (Table 5). Similar result was observed in Khaokaew and Khunthale sub-districts in wet season (Table 5).

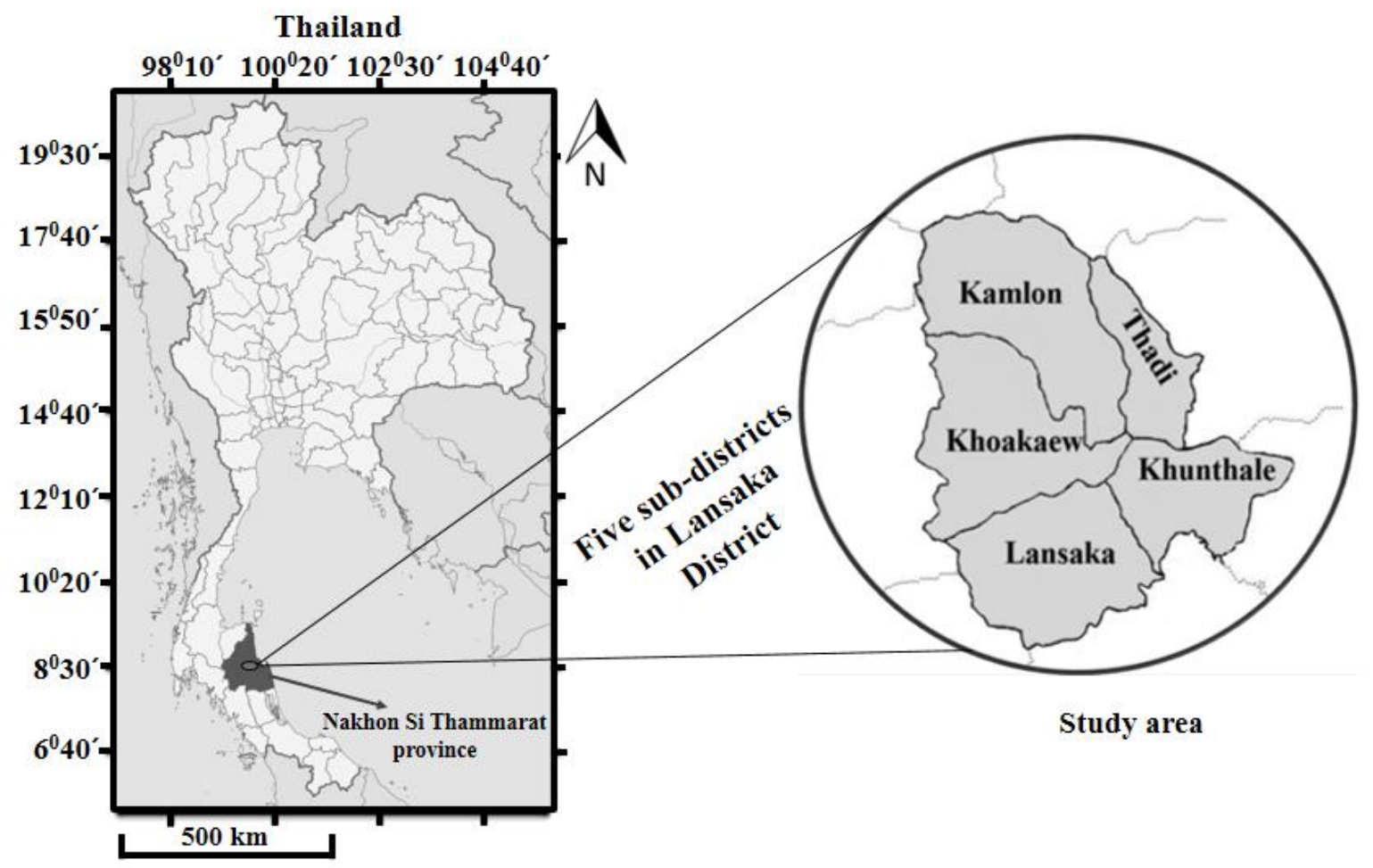

Figure 1 Location of Nakhon Si Thammarat province and Lansaka district inside Thailand map (left hand side). Study areas were five subdistricts in Lansaka district (right hand side).

Table 1 Environmental conditions in Lansaka district in 2018.

\begin{tabular}{lccc}
\hline Season & Mean temperature $\left({ }^{\circ} \mathrm{C}\right)$ & Mean rainfall $(\mathrm{mm})$ & Relative humidity $(\%)$ \\
\hline Dry & 28.48 & 97.87 & 84.89 \\
Wet & 26.76 & 641.00 & 90.08 \\
\hline
\end{tabular}

Table 2 Culex larvae numbers in the wet and dry seasons in five sub-districts in Lansaka district, Nakhon Si Thammarat, southern Thailand.

\begin{tabular}{|c|c|c|c|c|}
\hline \multirow{2}{*}{ Sub-district } & \multicolumn{2}{|c|}{ Season } & \multirow{2}{*}{ Total } & \multirow{2}{*}{ Statistical analysis } \\
\hline & Wet & Dry & & \\
\hline Khaokaew & 131 & 1000 & 1131 & $\chi^{2}{ }_{1}=665.03 *$ \\
\hline Lansaka & 23 & 699 & 722 & $\chi^{2}{ }_{1}=614.52 *$ \\
\hline Thadi & 67 & 319 & 386 & $\chi^{2}{ }_{1}=249.41 *$ \\
\hline Kamlon & 53 & 245 & 298 & $\chi^{2}{ }_{1}=177.39 *$ \\
\hline Khunthale & 180 & 279 & 459 & $\chi^{2}{ }_{1}=41.65^{*}$ \\
\hline Statistical analysis & $\chi^{2}=178.03^{*}$ & $\chi^{2}{ }_{4}=857.35^{*}$ & $\chi^{2}{ }_{4}=757.21^{*}$ & \\
\hline
\end{tabular}


Table 3 Culex larvae numbers in different types of containers in the five sub-districts.

\begin{tabular}{|c|c|c|c|c|c|c|c|c|c|c|c|c|c|}
\hline \multirow{2}{*}{ Season } & \multirow{2}{*}{ SD } & \multicolumn{12}{|c|}{ Numbers of Culex larvae } \\
\hline & & In-door & Out-door & Analysis & with lid & without lid & Analysis & Light & Dark & Analysis & Natural & Artificial & Analysis \\
\hline \multirow[t]{7}{*}{ Dry } & KHK & 40 & 960 & $\chi^{2}{ }_{1}=846.40^{*}$ & 75 & 925 & $\begin{array}{c}\chi^{2}= \\
722.50^{*}\end{array}$ & 8 & 992 & $\chi^{2}{ }_{1}=968.26^{*}$ & 10 & 990 & $\chi^{2}=960.40^{*}$ \\
\hline & LNS & 37 & 662 & $\chi^{2}{ }_{1}=558.83^{*}$ & 164 & 535 & $\begin{array}{c}\chi^{2}{ }_{1}= \\
196.91^{*}\end{array}$ & 90 & 609 & $\chi^{2}{ }_{1}=385.35^{*}$ & 0 & 699 & \\
\hline & $\mathrm{TD}$ & 16 & 303 & $\chi^{2}{ }_{1}=258.21^{*}$ & 0 & 319 & & 17 & 302 & $\chi^{2}{ }_{1}=254.62 *$ & 0 & 319 & \\
\hline & KL & 2 & 243 & $\chi^{2}{ }_{1}=237.07^{*}$ & 65 & 180 & $\chi^{2}{ }_{1}=53.98^{*}$ & 0 & 245 & & 22 & 223 & $\chi^{2}=164.90^{*}$ \\
\hline & KHT & 33 & 246 & $\chi^{2}{ }_{1}=162.61^{*}$ & 0 & 279 & & 46 & 233 & $\chi^{2}{ }_{1}=125.34^{*}$ & 0 & 279 & \\
\hline & Ana- & $\chi^{2}{ }_{4}=$ & $\chi^{2}{ }_{4}=$ & & $\chi^{2}{ }_{2}=$ & $\chi^{2}{ }_{4}=$ & & $\chi^{2}=$ & $\chi^{2}{ }_{4}=$ & & $\chi^{2}{ }_{1}=$ & $\chi^{2}{ }_{4}=$ & \\
\hline & lysis & $40.67^{*}$ & $840.39^{*}$ & & $58.63^{*}$ & $786.69^{*}$ & & $101.58^{*}$ & $895.91 *$ & & $4.50^{*}$ & $872.53 *$ & \\
\hline \multirow[t]{6}{*}{ Wet } & KHK & 0 & 131 & & 10 & 121 & $\chi^{2}{ }_{1}=94.05^{*}$ & 10 & 121 & $\chi^{2}{ }_{1}=94.05^{*}$ & 0 & 131 & \\
\hline & LNS & 0 & 23 & & 0 & 23 & & 0 & 23 & & 0 & 23 & \\
\hline & $\mathrm{TD}$ & 0 & 67 & & 0 & 67 & & 0 & 67 & & 0 & 67 & \\
\hline & KL & 0 & 53 & & 0 & 53 & & 0 & 53 & & 0 & 53 & \\
\hline & KHT & 111 & 69 & $\chi^{2}{ }_{1}=9.80^{*}$ & 0 & 180 & & 0 & 180 & & 0 & 180 & \\
\hline & $\begin{array}{l}\text { Ana- } \\
\text { lysis }\end{array}$ & & $\begin{array}{c}\chi^{2}{ }_{4}= \\
90.66^{*}\end{array}$ & & & $\begin{array}{c}\chi^{2}{ }_{4}= \\
173.88^{*}\end{array}$ & & & $\begin{array}{c}\chi^{2}{ }_{4}= \\
173.88 *\end{array}$ & & & $\begin{array}{c}\chi^{2}{ }_{4}= \\
178.03 *\end{array}$ & \\
\hline
\end{tabular}

$\mathrm{SD}=$ Sub-district, $\mathrm{KHK}=$ Khaokaew, $\mathrm{LNS}=$ Lansaka, $\mathrm{TD}=$ Thadi, $\mathrm{KL}=$ Kamlon, $\mathrm{KHT}=$ Khunthale * indicates $P<0.001$ 


\section{Discussion}

We observed higher numbers of Culex larvae in the dry season than in the wet season. Similar findings were reported by Mahadev et al (2004), Govoetchan et al (2014), and Manyi et al (2014) in Nigeria, India, and Benin. This could happen due to higher temperature in dry season than in wet season. Higher temperature may shorten larval and pupal development stages of mosquitoes. Shorter larval and pupal stages produce higher numbers of smaller-sized females which digest blood more often and produce more offspring (Githeko et al 2000; Promprou et al 2005; Kiarie-Makara et al 2015). The estimated optimum temperature for Culex mosquito developmental stages is $28.1{ }^{\circ} \mathrm{C}$ (Loetti et al 2011; KiarieMakara et al 2015), and the average temperature in the dry season in Lansaka district was $28.4{ }^{\circ} \mathrm{C}$ during conducting this study.

Higher numbers of Culex larvae were observed in outdoor, without a lid, dark, and artificial containers than in indoor, with a lid, light, and natural containers, respectively, in both the dry and wet seasons. Similar results were observed by Preechaporn et al (2007), Idowu et al (2012) and Thete and Shinde (2013). Other mosquito species (e.g., Aedes aegypti and Ae. albopictus), also prefer outdoor, without lid, dark, and artificial containers as their breeding habitats compared to indoor, with lid, light, and natural containers, respectively (Wongkoon et al 2007a; Idowu et al 2012; Thete and Shinde 2013). The reason behind preferring outdoor containers could be the higher amount of organic debris in them, which is important for larval development (Dom et al 2013). The female mosquitoes prefer artificial containers more than natural containers for breeding, and there could be two possible reasons behind this: (1) artificial containers (e.g., in this study, water storage containers) contain higher amounts of water compared to natural containers (e.g., in this study, coconut shell) and, possibly, Culex spp. requires higher amounts/levels of water for larval development, and (2) lower amounts of water in coconut shells get warmer more quickly compared to the higher amounts of water in water storage containers, and Culex spp. prefer cold environments more than hot environments (Preechaporn et al 2007; Aziz et al 2012). Preferences for the dark coloured containers in this study indicate that dark colours might act as attractants or ovipositioning stimulants for Culex females. According to Perea and Collaghan (2017), mosquitoes prefer to breed in dark coloured containers as dark-coloured containers possibly indicate a higher water level and a lower threat of desiccation before juvenile development. On the other hand, Williams (1962) and Hoel et al (2011) assume that colours may indicate higher concentrations of organic matter or nutrition inside the containers. Previously several studies have demonstrated a preference for female mosquitoes for oviposition in dark containers and in dark waters (Collins and Blackwell 2000; Hoel et al 2011; Panigrahi et al 2014; Perea and Collaghan 2017). There could be two possible explanations behind finding more mosquito larvae in containers without lids. First, female mosquitoes can easily enter the containers without lids compared to the containers with lids. Second, lids on the containers may prevent the access of insects and fallen leaves inside the containers, and thus, containers having lids might contain less organic matter compared to the containers without lids. Therefore, containers without lids might attract female mosquitoes more compared to the containers with lids.

Table 4 Total and positive containers in the five sub-districts in wet and dry seasons.

\begin{tabular}{|c|c|c|c|c|}
\hline \multirow[t]{2}{*}{ Sub-district } & \multirow{2}{*}{$\begin{array}{l}\text { Total /positive } \\
\text { containers }\end{array}$} & \multicolumn{2}{|c|}{ Season } & \multirow[t]{2}{*}{ Statistical analysis } \\
\hline & & Wet & Dry & \\
\hline \multirow[t]{2}{*}{ Khaokaew } & $\mathrm{T}$ & 566 & 67 & $\chi^{2}{ }_{1}=393.38^{* *}$ \\
\hline & $\mathrm{P}$ & 8 & 28 & $\chi^{2}{ }_{1}=11.11^{*}$ \\
\hline \multirow[t]{2}{*}{ Lansaka } & $\mathrm{T}$ & 522 & 37 & $\chi^{2}{ }_{1}=420.80 * *$ \\
\hline & $\mathrm{P}$ & 3 & 17 & $\chi^{2}{ }_{1}=9.80^{*}$ \\
\hline \multirow[t]{2}{*}{ Thadi } & $\mathrm{T}$ & 1130 & 52 & $\chi^{2}{ }_{1}=983.15^{* *}$ \\
\hline & $\mathrm{P}$ & 4 & 26 & $\chi^{2}{ }_{1}=16.13^{* *}$ \\
\hline \multirow[t]{2}{*}{ Kamlon } & $\mathrm{T}$ & 848 & 44 & $\chi^{2}{ }_{1}=724.68 * *$ \\
\hline & $\mathrm{P}$ & 5 & 17 & $\chi^{2}{ }_{1}=6.55^{*}$ \\
\hline \multirow[t]{2}{*}{ Khunthale } & $\mathrm{T}$ & 803 & 36 & $\chi^{2}{ }_{1}=701.18^{* *}$ \\
\hline & $\mathrm{P}$ & 8 & 16 & $\chi^{2}{ }_{1}=2.67^{n s}$ \\
\hline
\end{tabular}


Higher numbers of total containers were observed in the wet season in all sub-districts. A previous study (Chumsri et al 2018) also observed higher numbers of total containers in the wet season than in dry season. There are two possible reasons for higher numbers of total containers in wet season: (1) people in southern Thailand prefer to use rainwater for cooking, bathing, and other purposes, and for these reasons they use higher numbers of various types of containers to collect rain water (Wongkoon et al 2007a; Chumsri et al 2018), and (2) waste products, such as used styrofoam cups, bottles, and tyres, might collect rainwater, creating many suitable larval development sites for Culex larvae in the area.
Our results also showed that positive containers were more in the dry season compared to the wet season in most of the subdistricts, and there could be two possible explanations behind this. First, usually in the dry season, there is a lack of freshwater and thus water is stored in one container for a long time without cleaning it. Whereas, in the wet season, rainwater flushes out the stored water in a container more often. Therefore, in dry season, Culex larvae get a higher chance to stay in the same water for longer and finish their larval stages compared to the wet season. Secondly, there are very limited water storage containers available during the dry season, so most of them become key breeding sites for Culex females.

Table 5 Different kinds of containers in wet and dry seasons in five sub-districts. The numbers inside brackets are the numbers of $C u l e x$ larvae.

\begin{tabular}{|c|c|c|c|c|c|c|c|c|c|c|c|}
\hline \multirow[t]{3}{*}{ Season } & \multirow{3}{*}{$\begin{array}{l}\text { Container } \\
\text { types }\end{array}$} & \multicolumn{10}{|c|}{ Sub-districts } \\
\hline & & \multicolumn{2}{|c|}{ Khaokaew } & \multicolumn{2}{|c|}{ Lansaka } & \multicolumn{2}{|c|}{ Thadi } & \multicolumn{2}{|c|}{ Kamlon } & \multicolumn{2}{|c|}{ Khunthale } \\
\hline & & $\mathrm{T}$ & $\mathrm{P}$ & $\mathrm{T}$ & $\mathrm{P}$ & $\mathrm{T}$ & $\mathrm{P}$ & $\mathrm{T}$ & $\mathrm{P}$ & $\mathrm{T}$ & $P$ \\
\hline \multirow[t]{12}{*}{ Dry } & WSC & 49 & $21(877)$ & 27 & $11(540)$ & 27 & $\begin{array}{c}12 \\
(192)\end{array}$ & 37 & $14(211)$ & 21 & $11(124)$ \\
\hline & WPP & 0 & 0 & 1 & 0 & 3 & $2(43)$ & 1 & $1(2)$ & 2 & $1(75)$ \\
\hline & $\mathrm{RD}$ & 0 & 0 & 3 & $2(36)$ & 1 & 0 & 0 & 0 & 0 & 0 \\
\hline & $\mathrm{AG}$ & 0 & 0 & 0 & 0 & 0 & 0 & 0 & 0 & 0 & 0 \\
\hline & CS & 2 & $1(10)$ & 0 & 0 & 0 & 0 & 2 & $1(22)$ & 0 & 0 \\
\hline & ANC & 0 & 0 & 0 & 0 & 10 & $4(23)$ & 1 & 0 & 1 & 0 \\
\hline & $\mathrm{TC}$ & 13 & $5(78)$ & 5 & $3(63)$ & 8 & $6(47)$ & 2 & $1(10)$ & 8 & $4(80)$ \\
\hline & $\mathrm{CL}$ & 1 & 0 & 0 & 0 & 3 & $2(14)$ & 0 & 0 & 1 & 0 \\
\hline & $\mathrm{CMC}$ & 1 & $1(35)$ & 0 & 0 & 0 & 0 & 1 & 0 & 1 & 0 \\
\hline & RTKSC & 0 & 0 & 0 & 0 & 0 & 0 & 0 & 0 & 0 & 0 \\
\hline & AFP & 1 & 0 & 1 & $1(60)$ & 0 & 0 & 0 & 0 & 2 & 0 \\
\hline & Analysis & $\begin{array}{c}\chi_{5}^{2}= \\
163.78^{* *}\end{array}$ & $\begin{array}{c}\chi^{2}{ }^{3}= \\
38.86^{* *}\end{array}$ & $\begin{array}{c}\chi^{2}{ }^{2}= \\
66.38^{* *}\end{array}$ & $\begin{array}{c}\chi^{2}{ }_{3}= \\
14.77^{* *}\end{array}$ & $\begin{array}{c}\chi^{2}{ }_{5}= \\
53.23 * *\end{array}$ & $\begin{array}{c}\chi^{2}{ }^{2}= \\
13.23 *\end{array}$ & $\begin{array}{c}\chi^{2}= \\
144.18^{* *}\end{array}$ & $\begin{array}{c}\chi^{2}{ }_{3}= \\
29.82^{* *}\end{array}$ & $\begin{array}{c}\chi_{5}^{2}= \\
64.33^{*} *\end{array}$ & $\begin{array}{c}\chi_{2}^{2}= \\
9.88^{* * *}\end{array}$ \\
\hline \multirow[t]{12}{*}{ Wet } & WSC & 315 & 7 (128) & 322 & 0 & 460 & $1(20)$ & 318 & $3(28)$ & 287 & $6(162)$ \\
\hline & WPP & 131 & 0 & 115 & 0 & 340 & $1(37)$ & 336 & 0 & 330 & 0 \\
\hline & $\mathrm{RD}$ & 37 & 0 & 30 & 0 & 41 & 0 & 36 & 0 & 54 & 0 \\
\hline & $\mathrm{AG}$ & 23 & 0 & 20 & 0 & 36 & 0 & 32 & 0 & 14 & $1(3)$ \\
\hline & $\mathrm{CS}$ & 19 & 0 & 2 & 0 & 153 & 0 & 25 & 0 & 47 & 0 \\
\hline & ANC & 5 & 0 & 3 & $1(2)$ & 1 & 0 & 10 & $1(15)$ & 1 & 0 \\
\hline & $\mathrm{TC}$ & 18 & $1(3)$ & 18 & 0 & 71 & $2(10)$ & 44 & $1(10)$ & 51 & $1(15)$ \\
\hline & CL & 8 & 0 & 5 & 0 & 19 & 0 & 43 & 0 & 15 & 0 \\
\hline & $\mathrm{CMC}$ & 7 & 0 & 2 & $1(17)$ & 2 & 0 & 1 & 0 & 1 & 0 \\
\hline & RTKSC & 3 & 0 & 5 & $1(4)$ & 6 & 0 & 2 & 0 & 2 & 0 \\
\hline & AFP & 0 & 0 & 0 & 0 & 1 & 0 & 1 & 0 & 1 & 0 \\
\hline & Analysis & $\begin{array}{c}\chi^{2}{ }_{9}= \\
1538.52 * *\end{array}$ & $\begin{array}{l}\chi^{2}{ }_{1}= \\
4.50^{*}\end{array}$ & $\begin{array}{c}\chi^{2} 9= \\
1750.03 * \\
*\end{array}$ & $\begin{array}{l}\chi^{2}{ }_{2}= \\
0.00\end{array}$ & $\begin{array}{c}\chi^{2}{ }_{9}= \\
2364.98^{*} \\
*\end{array}$ & $\begin{array}{l}\chi^{2}{ }_{2}= \\
0.50\end{array}$ & $\begin{array}{c}\chi^{2}{ }_{9}= \\
2016.88^{*} \\
*\end{array}$ & $\begin{array}{l}\chi^{2} 2= \\
1.60\end{array}$ & $\begin{array}{c}\chi^{2}{ }^{2}= \\
1928.82^{* *}\end{array}$ & $\chi^{2}{ }_{2}=6.25^{*}$ \\
\hline
\end{tabular}

$\mathrm{T}=$ total containers, $\mathrm{P}=$ positive containers, WSC $=$ water storage container, $\mathrm{AFP}=$ animal feeding pans, $\mathrm{AG}=$ ant-guards, $\mathrm{RD}=$ refrigerator drainage, $\mathrm{ANC}$ $=$ areca nut containers, WPP $=$ water plant pots, $\mathrm{CL}=$ container lids, $\mathrm{TC}=$ trash containers, $\mathrm{CS}=$ coconut shells, $\mathrm{RTKSC}=$ rubber tapping $\mathrm{knife}$ sharpening containers, and $\mathrm{CMC}=$ cement mixing containers

** indicates $P<0.001$ and * indicates $P<0.05$

In this study, people in all sub-districts used more water-storing containers compared to other kinds of containers in both dry and wet seasons. Chen et al (2005) and Chumsri et al (2018) also found higher numbers of water-storing 
containers (total and positive) compared to other kinds of containers. Usually in Lansaka district, there is a lack of reliable water supply from municipality or administrative organization, and thus, people use higher number of water containers to store water for various purposes (e.g., drinking, bathing, cleaning, gardening and etc.). Moreover, people in this district plant various types of fruit trees (e.g., mangosteen, durian, rambutan, langsat/lanzones etc.) and that is why they need to store a higher amount of water for their orchard. Usually, they store water in large-sized cement jars and tanks for gardening purposes.

Among sub-districts, the numbers of total containers differed significantly in both the wet and dry seasons. In the wet season, higher numbers of containers were observed in Thadi sub-district than in other sub-districts because Thadi people prefer to keep higher numbers of plant pots around their houses, where rainwater gets easy access in the wet season. Another reason could be that the Thadi Administration does not provide rubbish/waste collection services in this subdistrict, and thus, Thadi people need to clean their own rubbish/wastes by themselves. In the dry season, it is easier for them to burn the wastes more often compared to the wet season because, in wet season, rainwater makes the wastes too wet to get burned. In the dry season, higher numbers of containers were observed in Khaokaew sub-district than in other sub-districts because people in this sub-district do not have a sustainable water supply and collect water from the nearby river; this was why they used a higher number of water-storing containers to store water in the dry season. The people of Khaokaew also have the habit of using and throwing a higher amount of refuse around their houses. As for the various container types, people from all sub-districts used higher numbers of water-storing containers compared to other types of containers. Similarly, Chen et al (2005), Rajesh et al (2013), and Vijayakumar et al (2014) observed higher numbers of water-storing containers, such as plastic containers or cement cisterns, compared to other type containers in Malaysia and India.

It was observed that the numbers of Culex spp. larvae were higher in the dry season than in the wet season, as well as higher in outdoor, without lid, dark and artificial containers than indoor, with lid, light and natural containers, respectively. Therefore, people should reduce the numbers of these containers, especially in the dry season, to prevent Culex borne diseases. Moreover, people should put lids on all containers at all times in order to prevent female mosquitoes from ovipositioning inside those containers.

\section{Acknowledgements}

We sincerely thank Mr. John Barker for improving the English text of this manuscript. The authors are grateful to the
Centre of Excellence for Ecoinformatics, Walailak University, Thailand for financial supports.

\section{References}

Ahmed TU, Rahman GMS, Bashar K, Shamsuzzaman M, Samajpati S, Sultana S, Hossain MI, Banu NN, Rahman MS (2007) Seasonal prevalence of dengue vector mosquitoes in Dhaka City, Bangladesh. Bangladesh Journal of Zoology 35:205-212.

Annual epidemiological surveillance report (2018) Bureau of Epidemiology, Department of Disease Control. Available from: https://ddc.moph.go.th

Aziz AT, Dieng H, Ahmad AH, Mahyoub JA, Turkistani AM, Mesed H, Koshike S, Satho T, Salmah MRC, Ahmad H, Zuharah WF, Ramli AS, Miake F (2012) Household survey of container-breeding mosquitoes and climatic factors influencing the prevalence of Aedes aegypti (Diptera: Culicidae) in Makkah City, Saudi Arabia. Asian Pacific Journal of Tropical Biomedicine 2:849-857.

Bartlett-Healy K, Unlu I, Obenauer P, Hughes T, Healy S, Crepeau T, Farajollahi A, Kesavaraju B, Fonseca D, Schoeler G, Gaugler R, Strickman D (2012) Larval mosquito habitat utilization and community dynamics of Aedes albopictus and Aedes japonicus (Diptera: Culicidae). Journal of Medical Entomology 49:813-824.

Chandra G, Ghosh A, Bhattacharjee I, Ghosh SK (2013). Use of larvivorous fish in biological and environmental control of disease vectors. In: Cameron MM, Lorenz L (eds) Biological and Environmental Control of Disease Vectors. Wallingford (UK), CAB International, pp 25-41.

Chen CD, Benjamin S, Saranum MM, Chiang YF, Lee HL, Nazni WA, Sofian-Azirun M (2005) Dengue vector surveillance in urban residential and settlement areas in Selangor, Malaysia. Tropical Biomedicine 22:39-43.

Chumsri A, TinaFW, Jaroensutasinee M, Jaroensutasinee K(2018) Seasons and socio-cultural practices affecting Aedes mosquito larvae in southern Thailand. Tropical Biomedicine 35:111-125.

Collins LE, Blackwell A (2000) Colour cues for oviposition behaviour in Toxorhynchites moctezuma and Toxorhynchites mboinensis mosquitoes. Journal of Vector Ecology, 25:127-135.

Dass K, Mariappan P (2014) Larvicidal activity of Lawsonia inermis and Murraya exotica leaves extract on filarial vector, Culex quinquefasciatus. International Journal of Mosquito Research, 1:2527.

Dom NC, Ahmad AH, Ismail R (2013) Habitat characterization of Aedes sp. breeding in urban hotspot area. Procedia-Social and Behavioral Sciences, 85:100-109.

Elizondo-Quiroga D, Medina-Sanchez A, Sanchez-Gonzalez JM, Eckert KA, Villalobos-Sanchez E, Navarro-Zuniga AR, SanchezTejeda G, Correa-Morales F, Gonzalez-Acosta C, Arias CF, Lopez S, Maria del Angel R, Pando-Robles V, Elizondo-Quiroga AE (2018) Zika virus in salivary glands of five different species of wild-caught mosquitoes from Mexico. Scientific reports, 8:809.

Erlanger TE, Weiss S, Keiser J, Utzinger J, Wiedenmayer K (2009) Past, present, and future of Japanese encephalitis. Emerging Infectious Diseases, 15:1-7.

Githeko AK, Lindsay SW, Confalonieri UE, Patz JA (2000) Climate change and vector-borne diseases: a regional analysis. Bulletin of the World Health Organization, 78:1136-1147.

Govoetchan R, Gnanguenon V, Azondekon R, Agossa RF, Sovi A, Oke-Agbo F, Osse R, Akogbeto M (2014) Evidence for perennial 
malaria in rural and urban areas under the Sudanian climate of Kandi, Northeastern Benin. Parasites \& Vectors, 7:79.

Guedes DRD, Paiva MHS, Donato MMA, Barbosa PP, Krokovsky L, dos S Rocha SW, Saraiva KLA, Crespo MM, Rezende TMT, Wallau GL, Barbosa RMR, Oliveira CMF, Melo-Santos MAV, Pena L, Cordeiro MT, de O Franca RF, de Oliveira ALS, Peixoto CA, Leal WS, Ayres CFJ (2017). Zika virus replication in the mosquito Culex quinquefasciatus in Brazil. Emerging Microbes \& Infections, 6:e69.

Guo X, Li C, Deng Y, Xing D, Liu Q, Wu Q, Sun A, Dong Y, Cao W, Qin C, Zhao T (2016) Culex pipiens quinquefasciatus: a potential vector to transmit Zika virus. Emerging Microbes \& Infections, 5:e102.

Hirzel A, Guisan A (2002) Which is the optimal sampling strategy for habitat suitability modelling. Ecological Modelling, 157:331-341.

Hoel DF, Obenauer PJ, Clark M, Smith R, Hughes TH, Larson RT, Diclaro JW, Allan SA (2011) Efficacy of ovitrap colors and patterns for attracting Aedes albopictus at suburban field sites in NorthCentral Florida. Journal of the American Mosquito Control Association, 27:245-251.

Hribar LJ (2006) Larval habitats of potential mosquito vectors of West Nile virus in the Florida Keys. Journal of Water and Health, 5:97-100.

Idowu OA, Adeleke MA, Aina TM (2012) Evaluation of indoor breeding activities of mosquitos during the dry season in Abeokuta, Southwestern Nigeria. Journal of Environmental Health Research, 12:25-30.

Kiarie-Makara MW, Ngumbi PM, Lee DK (2015) Effects of temperature on the growth and development of Culex pipiens complex mosquitoes (Diptera: Culicidae). IOSR-JPBS, 10:1-10.

Kumar R (2014) Prevention, diagnosis, and management of Japanese encephalitis in children. Pediatric Health, Medicine and Therapeutics, 5:99-110.

Lalubin F, Deledevant A, Glaizot O, Christe P (2013) Temporal changes in mosquito abundance (Culex pipiens), avian malaria prevalence and lineage composition. Parasites and Vectors, 6:307.

Lambdin BH, Schmaedick MA, McClintock S, Roberts J, Gurr NE, Marcos K, Waller L, Burkot TR (2009) Dry season production of filariasis and dengue vectors in American Samoa and comparison with wet season production. The American Journal of Tropical Medicine and Hygiene, 81:1013-1019.

Loetti V, Schweigmann NJ, Burroni NE (2011) Temperature effects on the immature development time of Culex eduardoi Casal and Garcia (Diptera: Culicidae). Neotropical Entomology, 40:138-142.

Mahadev PVM, Fulmali PV, Mishra AC (2004) A preliminary study of multilevel geographic distribution and prevalence of Aedes aegypti (Diptera: Culicidae) in the state of Goa, India. Indian Journal of Medical Research, 120:173-182.

Manyi MM, Vajime CG, Imandeh GN (2014) Seasonal changes of microfilarial infection and infectivity rates in mosquito populations within Makurdi, Benue State, Nigeria. International Journal of Mosquito Research, 1:1-9.

Nadeeka PVJ, Padhn G, Amarasinghe LD (2014) Geographic, economic and socio-cultural factors which defining the risk of dengue transmission in Kelaniya, Sri Lanka. Journal of Experimental Biology and Agricultural Sciences, 2:158-164.
Panigrahi SK, Barik TK, Mohanty S, Tripathy NK (2014) Laboratory evaluation of oviposition behavior of field collected Aedes mosquitoes. Journal of Insects, 2014: 207489.

Perea NO, Callaghan A (2017) Pond dyes are Culex mosquito oviposition attractants. PeerJ, 5:e3361.

Phuanukoonnon S, Mueller I, Bryan JH (2005) Effectiveness of dengue control practices in household water containers in Northeast Thailand. Tropical Medicine and International Health, 10:755-763.

Preechaporn W, Jaroensutasinee M, Jaroensutasinee K (2007) Seasonal prevalence of Aedes aegypti and Ae. albopictus in three topographical areas of southern Thailand. World Academy of Science, Engineering and Technology, 36:23-27.

Promprou S, Jaroensutasinee M, Jaroensutasinee K (2005) Climatic factors affecting dengue haemorrhagic fever incidence in southern Thailand. Dengue Bulletin, 29:41-48.

Promprou S, Jaroensutasinee M, Jaroensutasinee K (2007) High and low risk dengue haemorrhagic fever areas affecting key breeding place of Aedes aegypti (L.) and Ae. albopictus (Skuse) in Nakhon Si Thammarat, southern Thailand. Walailak Journal of Science and Technology, 4:9-22.

Rajesh K, Dhanasekaran D, Tyagi BK (2013) Survey of container breeding mosquito larvae (Dengue vector) in Tiruchirappalli district, Tamil Nadu, India. Journal of Entomology and Zoological Studies, $1: 88-91$.

Rattanarithikul R, Panthusiri P (1994) Illustrated keys to the medically important mosquitos of Thailand. The Southeast Asian Journal of Tropical Medicine and Public Health, 25:1-66.

Rattanarithikul R, Konishi E, Linthicum KJ (1996) Detection of Plasmodium vivax and Plasmodium falciparum circumsporozoite antigen in anopheline mosquitoes collected in southern Thailand. The Americal Journal of Tropical Medicine and Hygiene, 54:114-121.

Shad A, Andrew J (2016) A study on the seasonal prevalence of Culex quinquefasciatus larvae in Agra, Uttar Pradesh (India). International Journal of Mosquito Research, 3:52-55.

Thete KD, Shinde LV (2013) Survey of container breeding mosquito larvae in Jalna City (MS), India. Biological Forum- An International Journal, 5:124-128.

Vijayakumar K, Kumar TS, Nujum ZT, Umarul F, Kuriakose A (2014) A study on container breeding mosquitoes with special reference to Aedes (Stegomyia) aegypti and Aedes albopictus in Thiruvananthapuram district, India. Journal of Vector Borne Diseases, 51:27-32.

Webb C, Doggett S, Russell R (2016) A guide to mosquitoes of Australia. Csiro Publishing, Australia.

Williams RE (1962) The effect of coloration of oviposition media with regard to the mosquito Aedes triseriatus (Say). J. Parasitology. $\mathrm{PhD}$ dissertation, The Ohio State University.

Wongkoon S, Jaroensutasinee M, Jaroensutasinee K, Preechaporn W (2007a) Development sites of Aedes aegypti and Aedes albopictus in Nakhon Si Thammarat, Thailand. Dengue Bulletin, 31:141-152.

Wongkoon S, Jaroensutasinee M, Jaroensutasinee K, Preechaporn W, Chumkiew S (2007b) Larval occurrence and climatic factors affecting DHF incidence in Samui Islands, Thailand. World Academy of Science, Engineering and Technology, 33:5-10. 